\title{
ANALISIS PEMASARAN DAN PENDAPATAN USAHATANI SEMANGKA KELOMPOK TANI RIDHO LESTARI DI DESA TEMBOKREJO KECAMATAN MUNCAR KABUPATEN BANYUWANGI
}

\author{
Binta Islami Amnimarlianda ${ }^{1)}$, Imam Syafii ${ }^{2)}$ \& Agus Supriono ${ }^{2)}$ \\ 1) Mahasiswa Program Studi Agribisnis Fakultas Pertanian Universitas Jember \\ 2) Dosen Program Studi Agribisnis Fakultas Pertanian Universitas Jember \\ email: bintaislami25@gmail.com
}

\begin{abstract}
Increasing of watermelon demand stimulates farmer in Banyuwangi to rise area. However, farmer income of watermelon is still unclear. Besides, the marketing channel of watermelon affects farmer income. Banyuwangi Regency is one of the centers of watermelon production in East Java Province. The center of watermelon in Banyuwangi is Tembokrejo Village, Muncar sub-district. This research has three purposes: (1) to know the marketing channel of watermelon, (2) to know the margin and efficiency of watermelon marketing, and (3) to know the income and efficiency of watermelon farming. The results showed that farmers of watermelon farmer group Ridho Lestari have 4 marketing channels, namely: (a) farmers - wholesalers - retailers - consumers, (b) farmers - middlemen - wholesalers - retailers - consumers, (c) farmers - middlemen - retailers - consumers, and (d) farmers - exporters - importers; (2) the non-exported watermelon marketing margin is low and efficient, while the export marketing margin is high and inefficient; (3) Ridho Lestari farmers' watermelon farmer's income is beneficial and the cost of watermelon farming is efficient.
\end{abstract}

Key words: watermelon, marketing, income, cost efficiency.

\section{PENDAHULUAN}

Semangka merupakan komoditas hortikultura buah-buahan yang sangat populer dikalangan masyarakat Indonesia. Sebagaimana dikemukakan oleh Bappenas (2000), sentra penanaman semangka di Indonesia terdapat di; (a) Jawa Tengah, (b) Jawa Barat, (c) Jawa Timur, (d) Sumatera Barat, (e) Lombok dan (f) Lampung. Sentra penanaman semangka di Jawa Tengah terdapat di; (a) D. I. Yogyakarta, (b) Tegal, (c) Pekalongan, (d) Wonogiri, (e) Magelang dan (f) Kulonprogo; sedangkan sentra penanaman semangka di Jawa Barat berada di; (a) Indramayu dan (b) Karawang; dan sentra penanaman semangka di Jawa Timur terletak di; (a) Madiun, (b) Madura, (c) Malang, dan (d) Banyuwangi.

Luas panen semangka di Banyuwangi selalu meningkat dari tahun ke tahun. Hal ini dapat dilihat dalam kurun waktu 4 (empat) tahun terakhir yaitu dari tahun 2011 sampai dengan tahun 2014. Pada tahun 2011 luas panen semangka sebesar $1.621 \mathrm{Ha}$ dan meningkat pada tahun 2014 sebesar 2.259 Ha. Peningkatan luas panen ini menunjukkan bahwa lahan
Banyuwangi memang potensial untuk lahan bercocok tanam.

Sama halnya dengan luas panen semangka, produksi semangka di Banyuwangi juga tampak bahwa setiap tahunnya selalu mengalami peningkatan. Hal ini terlihat produksi semangka dari tahun 2011 sampai dengan tahun 2014. Pada tahun 2011 produksi semangka mencapai 33.526 ton dan pada tahun 2014 produksi semangka meningkat tajam hingga mencapai 63.342 ton.

Semangka yang dibudidayakan di Kabupaten Banyuwangi tersebar di beberapa wilayah kecamatan. Daerah yang menjadi sentra penghasil semangka di Banyuwangi diantaranya adalah Muncar, Srono, Tegaldlimo, dan Cluring. Muncar merupakan salah satu kecamatan di Banyuwangi yang berkontribusi sebagai kecamatan penghasil semangka dengan luas panen dan produksi paling tinggi. Luas panen semangka di Kecamatan Muncar pada tahun 2013 sebesar 1.913 Ha dan meningkat pesat pada tahun 2014 sebesar 3.128 Ha. Produksi semangka di Kecamatan Muncar pada tahun 2013 sebesar $269.809 \mathrm{kw}$ dan meningkat sebesar $389.375 \mathrm{kw}$ pada tahun 2014. Kontribusi luas 
panen semangka di Kecamatan Muncar sebesar $62,46 \%$ dan kontribusi produksi semangka di Kecamatan Muncar sebesar 65,40\%.

Desa di wilayah Kecamatan Muncar yang terkenal sebagai desa penghasil semangka adalah Desa Tembokrejo. Di Desa Tembokrejo terdapat banyak petani yang membudidayakan tanaman semangka. Akan tetapi, petani yang membudidayakan semangka di Desa Tembokrejo tidak seluruhnya tergabung dalam kelompok tani. Petani semangka di Desa Tembokrejo yang tergabung dalam kelompok tani berkumpul membentuk suatu kelompok dengan nama kelompok tani Ridho Lestari. Semangka yang dihasilkan oleh kelompok tani Ridho Lestari merupakan semangka terbaik di Kabupaten Banyuwangi. Menurut Tempo Bisnis (2015), kelebihan dari semangka Muncar ini yaitu kualitasnya baik dengan berat mencapai 6-7 kilogram per buah, rasanya lebih manis, tidak berbiji, dan pemeliharaannya menggunakan pupuk organik. Pemasaran semangka kelompok tani Ridho Lestari meliputi pemasaran ke kotakota besar di Pulau Jawa dan luar Pulau Jawa serta ekspor. Sedangkan pemasaran semangka yang diproduksi oleh petani semangka yang tidak tergabung dalam kelompok tani hanya meliputi pemasaran ke kota-kota besar di Jawa Timur dan daerah lokal.

Penelitian terkait pemasaran agribisnis sudah banyak dilakukan, diantaranya Efrizal dkk (2011), Ashilina dkk (2015). Kedua penelitian tersebut memiliki hasil yang berbeda, terutama pada pangsa pasar yang didapatkan oleh petani. Hal ini dikarenakan lokasi penelitian yang berbeda. Karenanya dihipotesiskan bahwa kondisi akan berbeda jika dilakukan di Banywangi.

Tujuan dari penelitian ini adalah (1) untuk mengetahui saluran pemasaran semangka yang terdapat pada kelompok tani Ridho Lestari Desa Tembokrejo Kecamatan Muncar Kabupaten Banyuwangi, (2) untuk mengetahui margin dan efisiensi pemasaran semangka pada kelompok tani Ridho Lestari Desa Tembokrejo Kecamatan Muncar Kabupaten Banyuwangi, (3) untuk mengetahui pendapatan dan efisiensi biaya usahatani semangka kelompok tani Ridho Lestari di Desa Tembokrejo Kecamatan Muncar Kabupaten Banyuwangi.

\section{METODE PENELITIAN}

Lokasi penelitian ditentukan secara sengaja yaitu di Desa Tembokrejo Kecamatan Muncar Kabupaten Banyuwangi. Penelitian ini menggunakan metode deskriptif dan analitik. Pengambilan contoh dilakukan dengan menggunakan 2 metode yaitu total sampling (petani semangka) dan purposive sampling (informan kunci dan ekspert). Metode pengumpulan data menggunakan wawancara mendalam. Analisis data menggunakan analisis deskriptif dan statistik deskriptif.

Guna mencapai tujuan pertama dalam penelitian ini, terkait bentuk saluran pemasaran semangka, metode yang digunakan adalah analisis deskriptif. Analisis deskriptif digunakan bertujuan untuk mendeskripsikan dan menginterpretasikan keadaan secara apa adanya sesuai dengan fenomena yang terjadi di lapang. Analisis deskriptif ditulis berdasarkan hasil wawancara dan pengamatan yang dilakukan di daerah penelitian. Jenis analisis deskriptif yang digunakan pada penelitian ini adalah analisis deskriptif studi kasus. Menurut Nazir (1988), analisis deskriptif studi kasus adalah penelitian tentang status subjek penelitian yang berkenan dengan suatu fase spesifik atau khas dari keseluruhan personalitas. Subjek penelitian dapat saja individu, kelompok, lembaga, maupun masyarakat. Peneliti ingin mempelajari secara intensif latar belakang serta interaksi lingkungan dari unit-unit sosial yang menjadi subjek.

Metode yang digunakan untuk mengetahui margin pemasaran semangka yaitu menggunakan rumus sebagai berikut (Sudiyono, 2002):

$$
\mathrm{MP}=\mathrm{Pr}-\mathrm{Pf}
$$

\section{Keterangan:}

MP = Margin pemasaran

$\operatorname{Pr} \quad=$ Harga yang dibayar konsumen

Pf = Harga yang diterima produsen

Kriteria pengambilan keputusannya yaitu semakin kecil nilai margin pemasaran, maka pemasaran semangka semakin efisien. Selain itu, pemasaran dikatakan efisien apabila nilai harga yang diterima petani semangka lebih besar dibandingkan dengan margin pemasaran keseluruhan.

Masing-masing lembaga pemasaran tentunya berusaha menarik keuntungan dari komoditas yang dijual, keuntungan dari masingmasing lembaga pemasaran adalah sebagai berikut:

Ski $=[\mathrm{Ki} /(\mathrm{Pr}-\mathrm{Pf})] \times 100 \%$ dimana

$\mathrm{Ki}=(\mathrm{Pj}-\mathrm{Pbi}-\mathrm{Bij})$

Keterangan: 
Ski = Share keuntungan lembaga ke- $i$

$\mathrm{Ki}=$ Keuntungan lembaga ke- $i$

$\mathrm{Pr} \quad=$ Harga yang dibayar konsumen

Pf = Harga yang diterima produsen

Pji = Harga jual lembaga ke- $i$

$\mathrm{Pbi}=$ Harga beli lembaga ke- $i$

Bij = Biaya pemasaran lembaga ke- $i$

Share biaya merupakan biaya-biaya pemasaran yang dikeluarkan oleh lembaga pemasaran terkait. Share biaya yang dikeluarkan lembaga pemasaran ke- $i$ adalah sebagai berikut:

Keterangan:

$$
\text { Sbi }=[\mathrm{bi} /(\mathrm{Pr}-\mathrm{Pf})] \times 100 \%
$$

Sbi = Share biaya lembaga ke- $i$

$\mathrm{Bi}=$ Biaya lembaga ke- $i$

$\mathrm{Pr} \quad=$ Harga yang dibayar konsumen

Pf = Harga yang diterima produsen

Kriteria pengambilan keputusan:

a. Jika Ski > Sbi maka saluran pemasaran semangka menguntungkan.

b. Jika Ski < Sbi maka saluran pemasaran semangka tidak menguntungkan.

Metode yang digunakan untuk mengetahui efisiensi pemasaran semangka yaitu menggunakan rumus sebagai berikut (Soekartawi, 1993):

Keterangan:

$$
\mathrm{EP}=\frac{\mathrm{TBP}(\mathrm{Rp})}{\mathrm{NP}(\mathrm{Rp})} \times 100
$$

$\mathrm{EP} \quad=$ Efisiensi pemasaran

TBP $=$ Total biaya pemasaran $/ \mathrm{kg}$

$\mathrm{NP}=$ Nilai produk yang dijual $/ \mathrm{kg}$

Kriteria pengambilan keputusan:

a. Jika EP kurang dari 50\% maka saluran pemasaran semangka efisien.

b. Jika EP lebih dari $50 \%$ maka saluran pemasaran semangka tidak efisien.

Metode yang digunakan untuk mengetahui pendapatan petani semangka yaitu menggunakan rumus (Soekartawi, 1995):

$$
\begin{aligned}
& \Pi=\mathrm{TR}-\mathrm{TC} \\
& \mathrm{TR}=\mathrm{P} \times \mathrm{Q} \\
& \mathrm{TC}=\mathrm{FC}+\mathrm{VC}
\end{aligned}
$$

Keterangan:

$$
\begin{array}{ll}
\Pi & =\text { Pendapatan } \\
\mathrm{TR} & =\text { Total revenue (total penerimaan) } \\
\mathrm{TC} & =\text { Total cost (total biaya) } \\
\mathrm{P} & =\text { Harga produk } \\
\mathrm{Q} & =\text { Volume produksi } \\
\mathrm{FC} & =\text { Fix cost (biaya tetap) } \\
\mathrm{VC} & =\text { Variabel cost (biaya tidak tetap) }
\end{array}
$$

Kriteria pengambilan keputusan:

a. Jika nilai TR $>$ TC, maka usahatani semangka menguntungkan.

b. Jika nilai $\mathrm{TR}=\mathrm{TC}$, maka usahatani semangka mengalami BEP (Break Event Point).

c. Jika nilai $\mathrm{TR}<\mathrm{TC}$, maka usahatani semangka mengalami kerugian.

Metode yang digunakan untuk mengetahui efisiensi biaya ushatani semangka yaitu menggunakan rumus (Soekartawi, 1995):

$$
R / C \text { Ratio }=\mathrm{TR} / \mathrm{TC}
$$

Keterangan:

TR = Total revenue (penerimaan total)

$\mathrm{TC}=$ Total cost (biaya total)

Kriteria pengambilan keputusan:

a. Jika nilai $R / C$ Ratio $>1$, maka penggunaan biaya usahatani semangka adalah efisien.

b. Jika nilai $R / C$ Ratio $<1$, maka penggunaan biaya usahatani semangka adalah tidak efisien.

c. Jika nilai $R / C$ Ratio $=1$, maka penggunaan biaya usahatani semangka adalah impas (BEP).

\section{HASIL DAN PEMBAHASAN}

\section{Saluran Pemasaran Semangka Kelompok} Tani Ridho Lestari

Kegiatan akhir dari sebuah usahatani adalah pemasaran. Pemasaran merupakan proses yang bertujuan untuk memuaskan kebutuhan dan keinginan konsumen (Budiarto, 1997). Pemasaran juga diartikan sebagai kegiatan penyaluran barang dari produsen kepada konsumen. Kegiatan penyaluran barang tersebut tentunya melibatkan satu atau lebih lembaga pemasaran. Lembaga pemasaran yang terlibat membentuk suatu saluran pemasaran. Menurut Chandra (2003), saluran distribusi adalah serangkaian organisasi yang saling terkait dan terlibat dalam proses penyampaian atau penyaluran barang dan jasa dari point of origin ke point of consumption guna memenuhi kebutuhan pelanggan secara menguntungkan. Berdasarkan penelitian yang dilakukan, saluran pemasaran semangka kelompok tani Ridho Lestari di Desa Tembokrejo Kecamatan Muncar Kabupaten Banyuwangi dapat dilihat pada gambar berikut. 


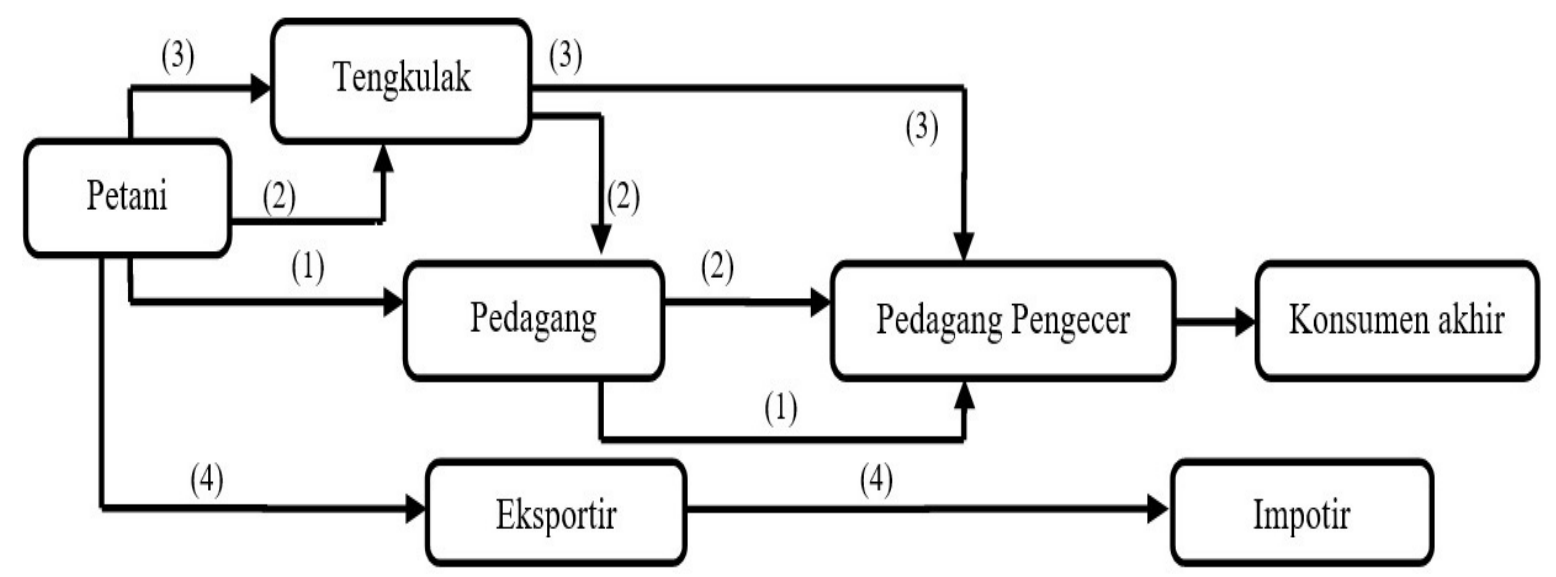

Gambar 1. Saluran Pemasaran Semangka Kelompok Tani Ridho Lestari

Berdasarkan skema saluran pemasaran semangka kelompok tani Ridho Lestari pada gambar 1, diketahui bahwa terdapat 4 saluran pemasaran semangka. Lembaga pemasaran yang terlibat pada pemasaran semangka kelompok tani Ridho Lestari terdiri dari 4 lembaga pemasaran yaitu tengkulak, pedagang besar, pedagang pengecer dan eksportir. Lembaga pemasaran tersebut mendistribusikan semangka melalui 4 saluran pemasaran sebagai berikut.

1. Saluran pemasaran 1 : Petani - Pedagang Besar - Pedagang Pengecer - Konsumen.

2. Saluran pemasaran 2 : Petani - Tengkulak - Pedagang Besar - Pedagang Pengecer Konsumen.

3. Saluran pemasaran 3 : Petani - Tengkulak Pedagang Pengecer - Konsumen.

4. Saluran pemasaran 4 : Petani - Eksportir Importir.

Saluran pemasaran semangka kelompok tani Ridho Lestari terdiri dari 4 saluran. Saluran pemasaran 1, 2, dan 3 merupakan saluran pemasaran semangka bukan ekspor, sedangkan saluran pemasaran 4 merupakan saluran pemasaran semangka ekspor. Semangka yang dipasarkan melalui saluran pemasaran bukan ekspor dibagi menjadi 2 grade yaitu grade B dan C. Semangka grade B adalah semangka dengan ciri-ciri berat $2-3 \mathrm{~kg}$, kondisi fisik buah tidak cacat dan tidak terlalu masak, sedangkan semangka grade $\mathrm{C}$ adalah semangka yang memiliki berat di bawah $2 \mathrm{~kg}$, kondisi fisik buah tidak cacat dan tidak terlalu masak. Semangka yang dipasarkan melalui saluran pemasaran ekspor hanya terdiri dari 1 grade yaitu grade A. Semangka grade A adalah semangka yang beratnya di atas $3 \mathrm{~kg}$, kondisi fisik buah tidak cacat dan tidak terlalu masak.
Pada saluran pemasaran 1, petani memasarkan semangka langsung kepada pedagang besar. Pedagang besar yang dimaksud adalah pedagang besar yang berada di pasar induk Surabaya, Jakarta, Kediri dan Bali. Prosesnya yaitu setelah petani melakukan pemanenan, semangka akan segera dikirim ke pedagang besar dengan menggunakan truk. Petani tidak melakukan sortasi terlebih dahulu. Setelah pedagang besar menerima semangka yang dikirim oleh petani, semangka disortasi terlebih dahulu oleh pedagang besar sebelum semangka dipasarkan kepada pedagang pengecer. Semangka yang disortasi oleh pedagang besar dibagi menjadi dua grade yaitu grade B dan $\mathrm{C}$, kemudian pedagang pengecer mendatangi pedagang besar di pasar induk untuk membeli semangka yang kemudian semangka tersebut langsung dijual ke konsumen akhir.

Pada saluran pemasaran 2, petani memasarkan semangka kepada tengkulak setelah semangka dipanen. Tengkulak membeli semangka ke petani dengan cara datang langsung ke sawah pada saat panen. Semangka yang dibeli oleh tengkulak tidak disortasi terlebih dahulu oleh petani. Tengkulak yang telah membeli semangka ke petani langsung mendistribusikan semangka ke pedagang besar. Pedagang besar yang dimaksud pada saluran pemasaran kedua adalah sama dengan pedagang besar yang dimaksud pada saluran pemasaran pertama yaitu pedagang besar yang berada di pasar induk Surabaya, Jakarta, Kediri dan Bali. Tengkulak mendistribusikan semangka ke pedagang besar dengan cara melakukan pengiriman menggunakan truk. Pedagang besar yang telah menerima semangka dari tengkulak melakukan sortasi terlebih dahulu sebelum 
semangka dibeli oleh pedagang pengecer. Pedagang besar melakukan sortasi semangka dengan membagi semangka menjadi dua grade yaitu grade B dan C. Selanjutnya pedagang pengecer membeli semangka ke pedagang besar dengan cara langsung datang ke pasar induk kemudian pedagang pengecer langsung menjual semangka kepada konsumen akhir.

Pada saluran pemasaran 3, semangka tidak dipasarkan ke luar kota tetapi hanya dipasarkan di wilayah Banyuwangi saja. Sama halnya dengan saluran pemasaran sebelumnya, petani tidak melakukan proses sortasi sebelum semangka didistribusikan ke tengkulak. Proses pemasaran semangka pada saluran ini yaitu tengkulak membeli semangka langsung datang ke sawah pada saat petani sedang panen. Selanjutnya tengkulak mendistribusikan semangka kepada pedagang pengecer yang berada di wilayah Banyuwangi. Pedagang pengecer membeli semangka ke tengkulak dengan mendatangi tengkulak secara langsung. Semangka yang telah dibeli oleh pedagang pengecer disortasi terlebih dahulu sebelum dijual ke konsumen. Semangka yang disortasi oleh pedagang pengecer dibagi menjadi dua grade yaitu grade B dan C. Semangka yang telah dibagi menjadi dua grade bisa langsung dijual kepada konsumen akhir.

Pada saluran pemasaran 4, semangka hanya didistribusikan ke luar negeri yaitu ke Singapura. Proses pemasaran semangka ekspor yaitu diawali dari petani melakukan pengiriman semangka kepada eksportir dengan menggunakan truk. Semangka yang dikirim menggunakan truk tersebut dikirim ke Bandung. Setelah semangka sampai di Bandung, semangka disortasi terlebih dahulu, diperiksa apakah ada semangka yang mengalami kerusakan atau tidak. Apabila seluruh semangka yang diterima masih dalam kondisi yang baik, semangka dikemas ke dalam karton, umumnya tiap karton berisi 16 $\mathrm{kg}$ semangka. Semangka yang telah dikemas ke dalam karton dibawa ke gudang, kemudian diangkat ke kontainer dan akan segera dikirim ke Bandara, setelah sampai di Bandara, semangka akan segera diterbangkan ke Singapura.

\section{Margin dan Efisiensi Pemasaran Semangka Kelompok Tani Ridho Lestari}

Marjin pemasaran (marketing margin) adalah harga yang dibiayai oleh konsumen dikurangi harga yang diterima oleh produsen. Tinggi rendahnya marjin pemasaran dipakai untuk mengukur efisiensi sistem pemasaran (tergantung dari fungsi pemasaran yang dijalankan). Semakin besar marjin pemasaran maka makin tidak efisien sistem pemasaran tersebut (Hanafie, 2010). Margin pemasaran diperhitungkan dengan nilai rupiah setiap $\mathrm{kg}$. Margin pemasaran hanya menunjukkan perbedaan harga yang dibayarkan konsumen dengan harga yang diterima petani, tetapi tidak menunjukkan jumlah produk yang dipasarkan. Besarnya margin pemasaran tergantung pada panjang atau pendeknya saluran pemasaran dan aktivitas-aktivitas yang telah dilaksanakan serta terdiri dari biaya dan keuntungan dari setiap lembaga pemasaran yang terlibat. Berikut adalah tabel margin pemasaran semangka kelompok tani Ridho Lestari pada saluran pemasaran 1 sampai dengan saluran pemasaran 4 .

Berdasarkan Tabel 1 di atas, diketahui pada saluran pemasaran 1, harga semangka di tingkat petani adalah $\mathrm{Rp} 4.500 / \mathrm{kg}$. Harga semangka grade B di tingkat konsumen adalah Rp 6.000/ $\mathrm{kg}$, sehingga margin pemasaran semangka pada saluran pemasaran 1 untuk semangka grade B adalah Rp 1.500/kg. Harga semangka grade C di tingkat konsumen sebesar Rp 5.500/kg, sehingga diperoleh margin pemasaran semangka grade $\mathrm{C}$ adalah Rp 1.000/kg.

Pada saluran pemasaran semangka 2, harga semangka di tingkat petani adalah $\mathrm{Rp}$ $3.500 / \mathrm{kg}$. Harga semangka grade B yang dibayar oleh konsumen adalah $\mathrm{Rp} 6.000 / \mathrm{kg}$, sehingga diperoleh margin pemasaran semangka pada

Tabel 1. Margin Pemasaran Semangka Kelompok Tani Ridho Lestari

\begin{tabular}{|c|c|c|c|c|c|c|}
\hline \multirow{2}{*}{ No } & \multirow{2}{*}{$\begin{array}{c}\text { Saluran } \\
\text { Pemasaran }\end{array}$} & \multirow{2}{*}{$\begin{array}{l}\text { Harga di tingkat } \\
\text { Petani }(\mathrm{Rp} / \mathrm{kg})\end{array}$} & \multicolumn{2}{|c|}{$\begin{array}{c}\text { Harga di tingkat Konsumen } \\
(\mathrm{Rp} / \mathrm{kg})\end{array}$} & \multicolumn{2}{|c|}{$\underset{\mathbf{k g})}{\operatorname{Margin}} \underset{\text { Pemasaran }}{(\mathbf{R p}} /$} \\
\hline & & & Grade B & Grade C & Grade B & Grade C \\
\hline 1 & Saluran & & 6000 & 5500 & 1500 & 1000 \\
\hline 2 & & & & & & 20 \\
\hline & Saluran 3 & 3400 & 4500 & 4000 & 1100 & 600 \\
\hline & Soluran 4 & 5500 & & & & \\
\hline
\end{tabular}


saluran pemasaran semangka 2 untuk semangka grade B adalah Rp 2.500/kg. Harga semangka grade $\mathrm{C}$ yang dibayar oleh konsumen sebesar $\mathrm{Rp}$ $5.500 / \mathrm{kg}$, sehingga diperoleh margin pemasaran semangka grade C adalah Rp 2.000/kg.

Pada saluran pemasaran semangka 3, petani menjual semangka dengan harga $\mathrm{Rp}$ $3.400 / \mathrm{kg}$. Konsumen membeli semangka grade B dengan harga $\mathrm{Rp} 4.500 / \mathrm{kg}$. Dari penjualan tersebut didapatkan margin pemasaran semangka grade B adalah Rp 1.100/kg. Untuk semangka grade $\mathrm{C}$, konsumen membeli dengan harga $\mathrm{Rp}$ $4.000 / \mathrm{kg}$, maka diperoleh margin pemasaran semangka grade $\mathrm{C}$ adalah $\mathrm{Rp} 600 / \mathrm{kg}$. Pada saluran pemasaran semangka 4 , harga semangka yang diterima petani adalah Rp 5.500/kg. Harga semangka yang dibayar oleh konsumen adalah Rp 17.500/kg. Dari penjualan tersebut, diketahui margin pemasaran sebesar Rp 12.000/kg.

\section{Share Keuntungan dan Share Biaya Pemasaran Semangka Kelompok Tani Ridho Lestari}

Masing-masing lembaga pemasaran yang terlibat dalam pemasaran semangka kelompok tani Ridho Lestari akan mengambil keuntungan dan akan mengeluarkan biaya selama proses pemasaran berlangsung. Keuntungan dari masing-masing lembaga pemasaran dan biaya yang dikeluarkan dinyatakan dalam satuan rupiah per $\mathrm{kg}$. Namun share keuntungan dan share biaya yang dikeluarkan dinyatakan dalam bentuk persentase. Berdasarkan analisis perhitungan margin pemasaran semangka, diperoleh share keuntungan dan share biaya pada masing-masing saluran pemasaran semangka dapat dilihat pada tabel 2 .

Berdasarkan Tabel 2, diketahui share keuntungan pada saluran pemasaran 1 semangka grade B adalah $92,45 \%$ dan share biayanya adalah $7,55 \%$ sedangkan share keuntungan semangka grade $\mathrm{C}$ adalah $91,76 \%$ dan share biayanya adalah $8,24 \%$. Share keuntungan pada saluran pemasaran 2 semangka grade B adalah 95,94\% dan share biayanya adalah 4,06 sedangkan share keuntungan semangka grade $\mathrm{C}$ adalah $95,57 \%$ dan share biayanya adalah $4,43 \%$. Share keuntungan pada saluran pemasaran 3 semangka grade B adalah $96,54 \%$ dan share biayanya adalah 3,46\% sedangkan share keuntungan semangka grade $\mathrm{C}$ adalah $96,11 \%$ dan share biayanya adalah 3,89\%. Share keuntungan pada saluran pemasaran 4 semangka grade A adalah $46,46 \%$ dan share biayanya adalah 53,53\%. Dari hasil tersebut, dapat dinyatakan saluran pemasaran semangka 1, 2 dan 3 adalah menguntungkan karena share keuntungan lebih besar daripada share biaya. Namun saluran pemasaran 4 tidak menguntungkan karena share keuntungan lebih kecil daripada share biaya.

\section{Efisiensi Pemasaran Semangka Kelompok Tani Ridho Lestari}

Tujuan akhir yang ingin dicapai dari proses pemasaran adalah efisiensi pemasaran yang dapat memberikan kepuasan kepada seluruh pelaku yang terlibat dalam pemasaran. Menurut Irawan (2007), secara teoritis efisiensi pemasaran merupakan maksimisasi rasio antara keluaran dan masukan yang digunakan dalam kegiatan pemasaran. Masukan yang dimaksud adalah berbagai sumberdaya ekonomi yang digunakan, sedangkan luaran yang diperoleh berupa jasa-jasa pemasaran yang dihasilkan dari pelaksanaan fungsi-fungsi pemasaran. Berdasarkan kriteria pengambilan keputusan, apabila nilai efisiensi pemasaran kurang dari 50\% maka saluran pemasaran efisien, sedangkan apabila nilai efisiensi pemasaran lebih dari $50 \%$ maka saluran pemasaran tidak efisien. Berikut adalah tabel hasil perhitungan efisiensi pemasaran semangka kelompok tani Ridho Lestari.

Tabel 2. Share Keuntungan dan Share Biaya Pemasaran Semangka Kelompok Tani Ridho Lestari

\begin{tabular}{|c|c|c|c|c|}
\hline \multirow{2}{*}{$\begin{array}{c}\text { Saluran } \\
\text { Pemasaran }\end{array}$} & \multicolumn{2}{|c|}{ Grade B } & \multicolumn{2}{|c|}{ Grade C } \\
\hline & Ski (\%) & Sbi (\%) & Ski (\%) & Sbi (\%) \\
\hline Saluran 1 & 92,45 & 7,55 & 91,76 & 8,24 \\
\hline Saluran 2 & 95,94 & 4,06 & 95,57 & 4,43 \\
\hline \multirow[t]{3}{*}{ Saluran 3} & 96,54 & 3,46 & 96,11 & 3,89 \\
\hline & \multicolumn{4}{|c|}{ Grade A } \\
\hline & \multicolumn{2}{|c|}{ Ski (\%) } & \multicolumn{2}{|c|}{ Sbi (\%) } \\
\hline Saluran 4 & \multicolumn{2}{|c|}{46,46} & \multicolumn{2}{|c|}{53,53} \\
\hline
\end{tabular}

Sumber: Data Primer Tahun 2017 
Tabel 3. Efisiensi Pemasaran Semangka Kelompok Tani Ridho Lestari

\begin{tabular}{|c|c|c|c|c|c|c|}
\hline \multirow[t]{2}{*}{ No } & \multirow{2}{*}{$\begin{array}{c}\text { Saluran } \\
\text { Pemasaran }\end{array}$} & \multirow{2}{*}{$\begin{array}{l}\text { Total Biaya } \\
\text { (Rp/kg) }\end{array}$} & \multicolumn{2}{|c|}{$\begin{array}{c}\text { Nilai produk yang dipasarkan } \\
(\mathrm{Rp} / \mathrm{kg})\end{array}$} & \multicolumn{2}{|c|}{$\begin{array}{c}\text { Efisiensi Pemasaran (Rp/ } \\
\text { kg) }\end{array}$} \\
\hline & & & Grade B & Grade C & Grade B & Grade C \\
\hline 1 & Saluran 1 & 473,06 & 6000 & 5500 & 7,55 & 8,24 \\
\hline 2 & Saluran 2 & 277,86 & 6000 & 5500 & 4,06 & 4,43 \\
\hline & Saluran 3 & 155,53 & 4500 & 4000 & 3,46 & 3,89 \\
\hline & & & \multicolumn{2}{|c|}{ Grade A } & \multicolumn{2}{|c|}{ Grade A } \\
\hline & Saluran 4 & 9370,32 & \multicolumn{2}{|c|}{17500} & \multicolumn{2}{|c|}{53,54} \\
\hline
\end{tabular}

Berdasarkan hasil analisis yang tersaji dalam Tabel 3, diketahui total biaya pada saluran pemasaran semangka 1 sebesar Rp 473,06/kg. Total biaya pada saluran pemasaran semangka 2 sebesar Rp 277,86/kg. Total biaya pada saluran pemasaran semangka 3 sebesar Rp 155,53/ $\mathrm{kg}$ dan total biaya pada saluran pemasaran semangka 1 sebesar Rp 9370,32/kg. Efisiensi pemasaran pada saluran pemasaran 1 semangka grade $\mathrm{B}$ adalah $7,55 \%$ dan semangka grade $\mathrm{C}$ adalah $8,24 \%$. Efisiensi pemasaran pada saluran pemasaran 2 semangka grade B adalah 4,06\% dan semangka grade $\mathrm{C}$ adalah $4,43 \%$. Efisiensi pemasaran pada saluran pemasaran 3 semangka grade $\mathrm{B}$ adalah $3,46 \%$ dan semangka grade $\mathrm{C}$ adalah 3,89\%. Efisiensi pemasaran pada saluran pemasaran 4 semangka grade A adalah 53,54. Saluran pemasaran semangka yang paling efisien adalah saluran pemasaran 3 semangka grade B sedangkan saluran pemasaran semangka yang paling tidak efisien adalah saluran pemasaran 4. Dari hasil tersebut, dapat dinyatakan bahwa saluran pemasaran semangka 1, 2 dan 3 adalah efisien karena nilai efisiensinya lebih kecil dari $50 \%$ sedangkan saluran pemasaran semangka 4 tidak efisien karena nilai efisiensinya lebih besar dari $50 \%$.

\section{Pendapatan Usahatani Semangka Kelompok Tani Ridho Lestari}

Pendapatan yang menguntungkan merupakan tujuan utama yang ingin dicapai oleh petani dalam menjalankan kegiatan usahataninya. Besarnya pendapatan yang diterima petani diperoleh dengan menghitung selisih antara total penerimaan dengan total biaya. Total penerimaan diperoleh dari jumlah produksi dikalikan dengan harga jual, sedangkan total biaya diperoleh dari jumlah seluruh biaya yang dikeluarkan selama kegiatan usahatani yang meliputi biaya tetap dan biaya variabel.

Berdasarkan Tabel 4, diketahui total penerimaan yang diterima petani adalah $\mathrm{Rp}$ 81.417.333,33. Besarnya total biaya usahatani semangka kelompok tani Ridho Lestari adalah $\mathrm{Rp}$ 43.111.462,50 yang diperoleh dari penjumlahan antara biaya tetap sebesar Rp 16.987.550 dan biaya variabel sebesar $\mathrm{Rp}$ 26.123.912,50. Pendapatan petani usahatani semangka kelompok tani Ridho Lestari adalah $\mathrm{Rp}$ 38.305.870,83. Pendapatan tersebut diperoleh dari hasil pengurangan antara total penerimaan dengan total biaya. Berdasarkan hasil perhitungan tersebut, diketahui penerimaan lebih besar dari total biaya, sehingga dapat dikatakan usahatani semangka kelompok tani Ridho Lestari adalah menguntungkan.

\section{Efisiensi Biaya Usahatani Semangka Kelompok Tani Ridho Lestari}

Efisiensi biaya merupakan perbandingan antara total penerimaan dengan total biaya. Umumnya hal ini disebut dengan $R / C$ Ratio. Analisis $R / C$ Ratio digunakan untuk mengetahui

Tabel 4. Rata-rata Pendapatan Usahatani Semangka Kelompok Tani Ridho Lestari per Musim Tanam per Ha

\begin{tabular}{cllr}
\hline No & \multicolumn{1}{c}{ Uraian } & Satuan & Jumlah \\
\hline 1 & Produksi & $\mathrm{Kg}$ & $19.395,9$ \\
2 & Harga & $\mathrm{Rp} / \mathrm{Kg}$ & 4.225 \\
3 & Total Penerimaan & $\mathrm{Rp}$ & $81.417 .333,33$ \\
4 & Total Biaya Tetap & $\mathrm{Rp}$ & 16.987 .550 \\
5 & Total Biaya Variabel & $\mathrm{Rp}$ & $26.123 .912,50$ \\
6 & Total Biaya & $\mathrm{Rp}$ & $43.111 .462,50$ \\
7 & Pendapatan & $\mathrm{Rp}$ & $38.305 .870,83$ \\
\hline Sumber: Data Primer Tahun 2017 & &
\end{tabular}


Tabel 5. Efisiensi Biaya Usahatani Semangka Kelompok Tani Ridho Lestari per Ha per Musim Tanam

\begin{tabular}{cllr}
\hline No & Uraian & Satuan & Jumlah \\
\hline 1 & Total Biaya & $\mathrm{Rp}$ & $43.111 .462,50$ \\
2 & Total Penerimaan & $\mathrm{Rp}$ & $81.417 .333,33$ \\
3 & Efisiensi Biaya & $\mathrm{Rp}$ & 1,89 \\
\hline Sumber: Data Primer Tahun 2017 & &
\end{tabular}

apakah penggunaan biaya pada usahatani semangka kelompok tani Ridho Lestari efisien atau tidak. Jika nilai $R / C$ Ratio lebih dari 1 maka penggunaan biaya pada usahatani semangka efisien. Jika nilai $R / C$ Ratio kurang dari atau sama dengan 1 maka penggunaan biaya pada usahatani semangka tidak efisien.

Berdasarkan hasil analisis yang tersaji pada Tabel 5 diketahui total penerimaan pada usahatani semangka kelompok tani Ridho Lestari sebesar $\mathrm{Rp}$ 81.417.333,33 dan total biaya sebesar $\mathrm{Rp}$ 43.111.462,50. Perbandingan antara total penerimaan dan total biaya tersebut, menghasilkan nilai $R / C$ Ratio usahatanisemangka sebesar 1,89 . Nilai tersebut menunjukkan bahwa jika petani mengeluarkan biaya sebesar Rp 1 maka petani akan mendapatkan penerimaan sebesar $\mathrm{Rp} 1,89$ per usahatani. Berdasarkan nilai $R / C$ Ratio di atas, maka dapat dikatakan penggunaan biaya pada usahatani semangka kelompok tani Ridho Lestari adalah efisien, karena nilai $R / C$ Ratio sebesar 1,89 adalah lebih besar dari 1, sehingga usahatani semangka kelompok tani Ridho Lestari dapat dikatakan layak untuk terus dijalankan oleh petani.

\section{SIMPULAN}

Saluran pemasaran yang digunakan oleh petani semangka kelompok tani Ridho Lestari terdiri dari 4 saluran pemasaran yaitu : (1) petani - pedagang besar - pedagang pengecer - konsumen, (2) petani - tengkulak - pedagang besar - pedagang pengecer - konsumen, (3) petani - tengkulak - pedagang pengecer konsumen, dan (4) petani - eksportir - importir.

Margin pemasaran semangka kelompok tani Ridho Lestari yang bukan ekspor adalah rendah, sedangkan margin pemasaran semangka ekspor adalah tinggi.

Efisiensi pemasaran semangka kelompok tani Ridho Lestari yang bukan ekspor adalah efisien, sedangkan efisiensi pemasaran semangka ekspor adalah tidak efisien.

Pendapatan petani semangka kelompok tani Ridho Lestari sebesar Rp 38.305.870,83/Ha/ MT artinya usahatani semangka kelompok tani
Ridho Lestari adalah menguntungkan.

Efisiensi biaya usahatani semangka kelompok tani Ridho Lestari sebesar 1,89 artinya penggunaan biaya pada usahatani semangka kelompok tani Ridho Lestari adalah efisien.

Sebaiknya petani semangka kelompok tani Ridho Lestari melakukan sortasi terlebih dahulu sebelum semangka didistribusikan kepada tengkulak atau pedagang besar dan memperhatikan harga jual yang ditawarkan oleh tengkulak dan pedagang besar dengan cara meminta harga semangka yang berbeda untuk setiap grade semangka yang dijual.

Sebaiknya petani semangka kelompok tani Ridho Lestari tidak perlu menggunakan saluran pemasaran semangka 4 karena saluran pemasaran tersebut margin pemasarannya tinggi, tidak efisien dan tidak menguntungkan.

\section{DAFTAR PUSTAKA}

Ashilina H., Setyowati, B.H. Utami. 2015. Analisis Pemasaran Semangka di Kecamatan Baki Kabupaten Sukoharjo. Agrista Vol. 3 No. 3.

Bappenas. 2000. Semangka. Jakarta: Sistim Informasi Manajemen Pembangunan di Perdesaan.

Budiarto, Teguh dan Fandy Ciptono. 1997. Pemasaran Internasional. Yogyakarta: BPFE.

Chandra, Gregorius., Tjiptono, Fandy., dan Chandra, Yanto. 2003. Pemasaran Global: Internasionalisasi dan Internetisasi. Yogyakarta: ANDI.

Efrizal, Y., M. Nurung., G. Mulyasari. 2011. Analisis Pendapatan, Efisiensi dan Pemasaran Semangka di Kampung Tempuran Kecamatan Trimurjo Kabupaten Lampung Tengah. Agrisep. Vol.10. No.2

Hanafie, Rita. 2010. Pengantar Ekonomi Pertanian. Yogyakarta: CV. Andi Offset. 
Irawan, Bambang. 2007. Fluktuasi Harga, Transmisi Harga, dan Margin Pemasaran Sayuran dan Buah. Jurnal Analisis Kebijakan Pertanian, 5 (4): 358 - 373.

Nazir, Moh. 1988. Metode Penelitian. Jakarta: Ghalia Indonesia.

Sudiyono. 2002. Pemasaran Pertanian. Malang: UMM Press.

Soekartawi. 1993. Prinsip Dasar Ekonomi Pertanian. Jakarta: Raja Grafindo Persada.

Soekartawi. 1995. Analisis Usahatani. Jakarta: Universitas Indonesia.

Tempo Bisnis. 2015. Semangka Banyuwangi di Ekspor ke Singapura.https://m.tempo.co/ read/news/2012/12/03/090445592/semangkabanyuwangi-diekspor-ke-singapura [diakses pada tanggal 01 Maret 2016 